\title{
Ventral slot in the clinical recovery of dogs with lateralized compression as a result of cervical intervertebral disc disease - 20 cases (2008-2018)
}

\author{
Marcelo Luís Schwab ${ }^{1}$ (D) Dênis Antonio Ferrarin ${ }^{1}$ (D) Angel Ripplinger ${ }^{1}$ (D) \\ Lícia Flávia Silva Herculano $^{1}$ Ana Caroline Teixeira Colvero ${ }^{1}$ (D) Mathias Reginatto Wrzesinski $^{1}$ (iD \\ Júlia da Silva Rauber ${ }^{1}$ (D) Samanta Simon Moro ${ }^{2}$ Graciane Aiello ${ }^{3}$ Alexandre Mazzanti ${ }^{4}$ (D)
}

\footnotetext{
'Programa de Pós-graduação em Medicina Veterinária, Serviço de Neurologia e Neurocirurgia Veterinária (SNNV), Hospital Veterinário Universitário (HVU), Centro de Ciências Rurais (CCR), Universidade Federal de Santa Maria (UFSM), Santa Maria, RS, Brasil.

${ }^{2}$ Médica Veterinária Autônoma, Porto Alegre, RS, Brasil.

${ }^{3}$ Departamento de Clínica e Cirurgia de Pequenos Animais, Universidade do Oeste de Santa Catarina (UNOESC), Xanxerê, SC, Brasil.

${ }^{4}$ Departamento de Clínica de Pequenos Animais, Serviço de Neurologia e Neurocirurgia Veterinária (SNNV), Hospital Veterinário Universitário (HVU), Centro de Ciências Rurais (CCR), Universidade Federal de Santa Maria (UFSM), 97105-900, RS, Brasil. E-mail: alexamazza@yahoo.com.br. ${ }^{*}$ Corresponding author.
}

ABSTRACT: The objective of this study was to verify the clinical recovery of dogs that underwent ventral slot surgical decompression with lateralized compressions of the cervical spinal cord caused by intervertebral disc disease (IVDD). Twenty patients were selected in different degrees of neurological dysfunction with definitive diagnosis of lateralized compression by cervical IVDD. Postoperative clinical recovery was assessed in patients who had undergone at least two months of the surgical procedure. There was a satisfactory recovery in 19 dogs $(95 \%)$ and unsatisfactory recovery in another $(5 \%)$, showing a significant clinical improvement $(p<0.05)$ in the use of this technique in lateralized compression cases. The ventral slot promotes satisfactory clinical recovery of dogs with lateralized compression of the spinal cord caused by cervical IVDD and may be indicated as a surgical alternative.

Key words: spinal cord compression, cervical disk disease, ventral slot, surgery, dogs.

Fenda (slot) ventral na recuperação clínica de cães com compressões lateralizadas em decorrência da doença do disco intervertebral cervical - 20 casos (2008-2018)

RESUMO: $O$ objetivo desse estudo foi verificar a recuperação clínica de cães submetidos a descompressão cirúrgica por fenda ventral em compressões lateralizadas da medula espinhal cervical ocasionada pela doença do disco intervertebral (DDIV). Foram selecionados 20 pacientes em diferentes graus de disfunção neurológica com diagnóstico definitivo de compressões lateralizadas por DDIV cervical. A recuperação clínica pós-operatória foi avaliada nos pacientes decorridos, no mínimo, dois meses do procedimento cirúrgico. Houve recuperação satisfatória em 19 cães (95\%) e um insatisfatório (5\%), demonstrando melhora clínica significativa (p<0,05) no emprego desta técnica em casos de compressões lateralizadas. A fenda ventral promove recuperação clínica satisfatória de cães com compressões lateralizadas da medula espinhal, ocasionadas pela DDIV cervical, e pode ser indicada como alternativa cirúrgica.

Palavras-chave: compressão medular, doença do disco intervertebral cervical, fenda ventral, cirurgia, cães.

\section{INTRODUCTION}

The intervertebral disc disease (IVDD) is the main cause of compressive myelopathy in dogs and mainly affects chondrodystrophic breeds such as Dachshund, Poodle Toy, Pekingese, Beagle, Lhasa Apso, Shih Tzu and Cocker Spaniel (GRIFFIN et al., 2009; BRISSON, 2010; CHAVES et al., 2014). It can involve any segment of the spinal cord, and the cervical region corresponds to $12.9 \%$ to $25.4 \%$ of the herniated discs (BRISSON, 2010). IVDD can be classified as type I or extrusion, II or protrusion (HANSEN, 1952), acute non-compressive nucleus pulposus extrusion (DE RISIO et al., 2009), and discal cysts (KONAR et al., 2008). In the cervical region, clinical signs range from cervical hyperesthesia to non-ambulatory tetraparesis (TANAKA et al., 2005).

Treatment for cervical IVDD can be performed by clinical management or by surgical decompression of the spinal cord (BRISSON, 2010; FINGEROTH, 2017). Several surgical techniques were described including ventral slot, dorsal 
laminectomy and hemilaminectomy. Ventral slot is the most commonly used technique in routine because it provides direct access of the intervertebral disc and is associated with good functional recovery indexes (SEIM \& PRATA, 1982; TANAKA et al., 2005; DA COSTA, 2017).

The ventral slot allows the ventral view of the cervical spinal cord (DA COSTA, 2017) not being indicated for lateralized lesions (LIPSITZ \& BAILEY, 1992; LIPSITZ \& BAILEY 1995; FINGEROTH, 2017). For this type of compression, the recommended surgical technique is hemilaminectomy which allows lateral and ventral access of the spinal cord (FELTS \& PRATA 1983; LIPSITZ \& BAILEY, 1992; LIPSITZ \& BAILEY 1995; ROSSMEISL et al., 2005; TANAKA et al., 2005).

Although, hemilaminectomy was indicated in the surgical treatment in lateralized compression of the spinal cord (FAUBER \& BERGMAN, 2017), there are no references for the use of the ventral slot in these types of situations. Thus, there is doubt whether this technique is effective in the clinical recovery of dogs presenting lateralized compression of the spinal cord by intervertebral disc contents.

Therefore, due to lack of study on the subject, the purpose of this study was to verify if the ventral slot technique allows for clinical recovery of lateralized compressions caused by the intervertebral disc disease.

\section{MATERIALS AND METHODS}

Dogs with a definitive diagnosis of cervical IVDD type I (extrusion) and II (protrusion) were included. They were all seen by the neurology and neurosurgery sector of a Higher Education Institution, between May 2008 and June 2018. As inclusion criterion, only dogs with complete clinical record (signalment, history, physical and neurological examination), myelography or tomography with identification of lateralized spinal cord compression and that were submitted to the surgical procedure of ventral slot by the same surgeon, according to the technique described by DA COSTA (2017).

According to the clinical records, the degree of neurological dysfunction of all dogs was classified as 1 to 4 , in which 1 meant only cervical hyperesthesia, 2-mild ambulatory tetraparesis without falls, 3 - moderate ambulatory tetraparesis and 4 - non - ambulatory tetraparesis (TANAKA et al., 2005).

Myelography and computed tomography were evaluated by a veterinarian with experience in image interpretation of the spinal cord. Lesions were considered lateralized when there was ventrolateral compression within the vertebral canal, evidenced in the ventral and/or oblique views and located primarily on one side of the midline with or without extension to the intervertebral foramen (ROSSMEISL et al., 2005).

Compressions were also classified according to a lateralization grading system. For this purpose, with the aid of the Animati PACS ${ }^{\circledR}$ software, the spinal canal was measured, a vertebra ahead of the compression site, and at the point of greatest spinal cord compression, in the oblique views. Based on these values, the lateralization degree was estimated as percentage and classified as mild, when there was $<25 \%$ of the spinal cord compressed, moderate between $25 \%$ to $50 \%$ and intense for compressions $>50 \%$.

Postoperative clinical recovery was assessed in patients who had undergone at least two months of the surgical procedure. Owners have answered a modified questionnaire, via telephone, following the methodology used by LEVINE et al. (2007) in their study to evaluate the clinical recovery of patient with thoracolumbar IVDD in dogs treated conservatively.

The recovery was classified as satisfactory for those dogs that recovered the ability to walk without falls and without cervical hyperesthesia; partially satisfactory for those who recovered the ability to walk without falls but with persistent cervical hyperesthesia and unsatisfactory when they did not recover the ability to walk and remained with cervical hyperesthesia or when there was deterioration of neurological signs. The dogs that had satisfactory clinical improvement after the surgical procedure and who again developed signs of cervical myelopathy caused by intervertebral disc compression were classified as recurrence (SCHMIED et al., 2011).

Statistical analysis was performed by the Statistical Analysis System (SAS), Version 9.2 program with significance level $\mathrm{p}<0.05$. The chisquare test was used to evaluate the post-surgical clinical evolution by ventral slot for patients with lateralized compressions and to determine if the lateralization degree infers with the outcome.

\section{RESULTS}

We reported 61 records of patients with definitive diagnosis of cervical IVDD (Hansen type I and II) who underwent decompression surgery using the ventral slot surgical technique. Of these, only 23 patients met the pre-established inclusion criteria, and three owners did not respond to the questionnaire, totaling 20 patients.

The studied population was represented by $57.9 \%(\mathrm{n}=11)$ of Dachshund dogs. Other breeds 
included Beagle, Dalmatian $(\mathrm{n}=2)$, and Yorkshire Terrier $(n=1)$. Four dogs had no defined breed. The age ranged from three to 14 years, with the mean age being 8.05 years $( \pm 2.56)$. As for the sex, $70 \%(n=14)$ of the dogs were males and $30 \%(n=6)$ were females.

Myelography exam was performed in 19 dogs and computed tomography in just one. The most affected intervertebral space was $\mathrm{C} 2-\mathrm{C} 3$ with $35 \%(\mathrm{n}=7)$ of the compressions. There was spinal cord compression between $\mathrm{C} 3-\mathrm{C} 4$ in $30 \%(n=6)$ of cases, between $\mathrm{C} 4-\mathrm{C} 5$ in $10 \%(\mathrm{n}=2)$ and in $\mathrm{C} 5-\mathrm{C} 6$ in $25 \%(\mathrm{n}=5)$. In $90 \%(\mathrm{n}=18)$ of the compressions there was extrusion of the nucleus pulposus (Hansen type I) and in $10 \%(\mathrm{n}=2)$ there was protrusion of the annulus fibrosus (Hansen type II).

As for the degree of preoperative neurological dysfunction, $10 \%(n=2)$ of the patients were in grade $1,25 \%(\mathrm{n}=5)$ in grade $2,10 \%(\mathrm{n}=$ $2)$ in grade 3 and $55 \%(n=11)$ in grade 4 . After a surgical procedure, only one dog $(5 \%)$ remained neurologically deficient, being classified in grade 1 . In 19 dogs $(95 \%)$, there was a satisfactory recovery and one (5\%) was unsatisfactory, and the Chi-Square test showed a significant postoperative clinical response using the ventral slot technique $(\mathrm{p}<0.05)$. There was recurrence of clinical signs after six months postoperatively in only one $(5 \%)$ patient at a site other than the first compression. No patient died during surgery.

Regarding the lateralization degree of the compression, $35 \%(\mathrm{n}=7)$ were classified as mild, $50 \%(\mathrm{n}=10)$ as moderate and $15 \%(\mathrm{n}=3)$ as intense. Statistically the lateralization degree did not affect the patient's outcome.

The distribution according to sex, breed, age, lesion location, preoperative neurological grade, lateralization degree and outcome of dogs with cervical IVDD submitted to surgery by the ventral slot technique is described in table 1 .

\section{DISCUSSION}

The recommended surgical technique for decompression of the spinal cord in dogs affected

Table 1 - Distribution by sex, breed, age, lesion location, preoperative neurological grade, lateralization degree, and outcome of 20 dogs with cervical intervertebral disc disease submitted to the ventral slot technique.

\begin{tabular}{|c|c|c|c|c|c|c|c|}
\hline $\begin{array}{l}\text { Dog } \\
\left(n^{\circ}\right)\end{array}$ & Sex & Breed & Age (years) & $\begin{array}{l}\text { Lesion } \\
\text { location }\end{array}$ & $\begin{array}{c}\text { Preoperative } \\
\text { neurological grade }\end{array}$ & $\begin{array}{c}\text { Lateralization } \\
\text { degree }(\%)\end{array}$ & Outcome \\
\hline 1 & M & Dalmatian & 8 & C5-C6 & 4 & II (38.46) & $\mathrm{S}$ \\
\hline 2 & M & Mixed breed & 8 & $\mathrm{C} 2-\mathrm{C} 3$ & 3 & II (33.33) & $\mathrm{S}$ \\
\hline 3 & M & Mixed breed & 8 & $\mathrm{C} 2-\mathrm{C} 3$ & 2 & III (60.00) & $\mathrm{S}$ \\
\hline 4 & M & Mixed breed & 10 & $\mathrm{C} 3-\mathrm{C} 4$ & 2 & I (18.75) & $\mathrm{S}$ \\
\hline 5 & M & Dachshund & 10 & $\mathrm{C} 4-\mathrm{C} 5$ & 4 & II (29.41) & $\mathrm{S}$ \\
\hline $6^{*}$ & $\mathrm{~F}$ & Dachshund & 6 & $\mathrm{C} 2-\mathrm{C} 3$ & 4 & III (72.22) & $\mathrm{S}$ \\
\hline 7 & $\mathrm{~F}$ & Dachshund & 8 & $\mathrm{C} 3-\mathrm{C} 4$ & 2 & III (68.42) & $\mathrm{S}$ \\
\hline 8 & M & Beagle & 11 & $\mathrm{C} 2-\mathrm{C} 3$ & 4 & I (11.76) & $\mathrm{S}$ \\
\hline 9 & M & Dachshund & 9 & $\mathrm{C} 4-\mathrm{C} 5$ & 2 & II (44.00) & $\mathrm{S}$ \\
\hline 10 & M & Dachshund & 7 & C5-C6 & 4 & II (27.27) & $\mathrm{S}$ \\
\hline 11 & M & Dachshund & 8 & $\mathrm{C} 2-\mathrm{C} 3$ & 4 & I (12.50) & $\mathrm{S}$ \\
\hline 12 & M & Yorkshire & 9 & $\mathrm{C} 3-\mathrm{C} 4$ & 4 & II (27.27) & $\mathrm{S}$ \\
\hline 13 & $\mathrm{~F}$ & Dachshund & 7 & $\mathrm{C} 2-\mathrm{C} 3$ & 1 & II (31.25) & $\mathrm{S}$ \\
\hline 14 & $\mathrm{~F}$ & Dachshund & 3 & $\mathrm{C} 3-\mathrm{C} 4$ & 2 & II (26.66) & $\mathrm{S}$ \\
\hline 15 & $\mathrm{~F}$ & Dachshund & 5 & $\mathrm{C} 3-\mathrm{C} 4$ & 4 & I (20.00) & $\mathrm{S}$ \\
\hline 16 & M & Dalmatian & 14 & $\mathrm{C} 2-\mathrm{C} 3$ & 4 & I (20.00) & $\mathrm{S}$ \\
\hline 17 & M & Dachshund & 5 & $\mathrm{C} 3-\mathrm{C} 4$ & 4 & II (46.66) & $\mathrm{S}$ \\
\hline 18 & M & Mixed breed & 7 & C5-C6 & 2 & II (44.44) & $\mathrm{S}$ \\
\hline 19 & M & Beagle & 12 & C5-C6 & 4 & I (16.66) & $\mathrm{S}$ \\
\hline 20 & $\mathrm{~F}$ & Dachshund & 6 & C5-C6 & 1 & I (17.64) & $\mathrm{U}$ \\
\hline
\end{tabular}


by cervical IVDD with lateralized compression is the hemilaminectomy, which allows lateral surgical access to the vertebral canal, in addition to allowing visualization of the ventral and dorsal regions (ROSSMEISL et al., 2005; TANAKA et al., 2005; SCHMIED et al., 2011; TAYLOR-BROWN et al., 2015). However, TANAKA et al. (2005) reported the need to incise a large number of muscles, making surgical access to hemilaminectomy more complicated when compared to other techniques. In addition, the high degree of bleeding, often resulting from the internal intervertebral venous plexus lesion, makes it difficult to see the spinal cord and nerve roots, which can lead to iatrogenic lesions and hypotension (FINGEROTH, 2017).

Another limitation of cervical hemilaminectomy is related to intervertebral disc fenestration, a procedure not necessary in the ventral slot technique, since the affected disc is totally removed in this type of surgical access (BRISSON, 2017). Although, studies have shown lower rates of recurrence when using disk fenestration for the thoracolumbar region after hemilaminectomy (BRISSON et al., 2004; AIKAWA et al., 2012), no indication of intervertebral disc fenestration has been reported in the literature cervical hemilaminectomy, which could increase the chances of recurrence in this region.

In the ventral slot decompression technique, the literature mentioned a limited visibility of the vertebral canal allowing only manipulation in the ventral region, not being sufficient for lateralized and dorsal decompression (FELTS \& PRATA 1983; LIPSITZ \& BAILEY 1992; FINGEROTH, 2017). However, in this study, the ventral slot even with limited access proved to be effective also in cases of lateralized compression $(p<0.05)$, since it allowed the removal of the extruded or protruding material inside the vertebral canal with satisfactory post-operative clinical evolution in $95 \%$ of patients $(19 / 20)$.

Regarding the clinical evolution, only one dog (no 20) continued with cervical spinal hyperesthesia in the postoperative period. Studies have shown worse results regarding the functional recovery of patients for those who have lesions in the caudal cervical spine (FITCH et al., 2000; ROSSMEISL et al., 2013), a fact observed in this patient since the patient presented spinal compression between $\mathrm{C} 5$ C6. The owner decided for a new surgical procedure performed by hemilaminectomy, but this patient died during the procedure. At necropsy, disc contents were present on the cranial border of the fifth vertebra (C5) with involvement of the nerve root between C4-C5. A probable explanation for the presence of the contents in this region may have been the difficulty of ventral access for removal of material at the vertebral extremities or the displacement of the cranial contents in the attempt of removal at the first surgery.

The persistence of pain in the postoperative period is considered a major adverse event when using the ventral slot surgical technique and usually requires new surgical intervention (ROSSMEISL et al., 2013). This was observed in the patient (no 20), whose result was similar to the findings of ROSSMEISL et al. (2013), in which $4 \%$ of the animals remained with pain in the postoperative period.

Claudication of the thoracic limb can be observed in dogs with cervical IVDD and is generally related to nerve root compression by disc content (root sign) (BRISSON, 2010; FAUBER \& BERGMANN, 2017). In this research, two dogs presented this signal and even the ventral slot technique did not allow nerve root exposure (FAUBER \& BERGMANN 2017), it was possible to decompress this structure and improve claudication in the immediate postoperative period.

The trans-operative death rate of $6.3 \%$ related to complications inherent to the ventral slot procedure was described in the study by SMITH et al. (1997); in the research of ROSSMEISL et al., (2013) this was negative. In this study death rate was also negative. $\operatorname{Dog} n^{\circ} 20$, that performed a second procedure (hemilaminectomy), probably died due to anesthetic complications, since there was no intercurrence during the surgical procedure and also because it was not possible to define the cause of death at necropsy.

The rate of recurrence in this study was $5 \%$ and occurred in a dog $\left(n^{\circ} 6\right)$ that showed signs of spinal hyperesthesia after six months postoperatively of the first surgery. When performing another myelography, there was extradural compression in another intervertebral space (C5-C6) than the one initially operated (C2-C3) (Figure 1). For this, was established a protocol of clinical treatment. During the first myelogram; however, it was possible to observe calcification of the intervertebral disc between C5-C6 and this finding is a factor that increases the predisposition to intervertebral disc extrusion (JENSEN et al., 2008). The rate of recurrence reported in this study was similar to that reported in SCHMIED et al. (2011) when using the hemilaminectomy technique for the treatment of cervical IVDD.

Both techniques of hemilaminectomy and ventral slot have advantages and disadvantages already mentioned previously for the treatment of lateralized lesion by IVDD. However, our study refutes the concept that the ventral slot is not a 


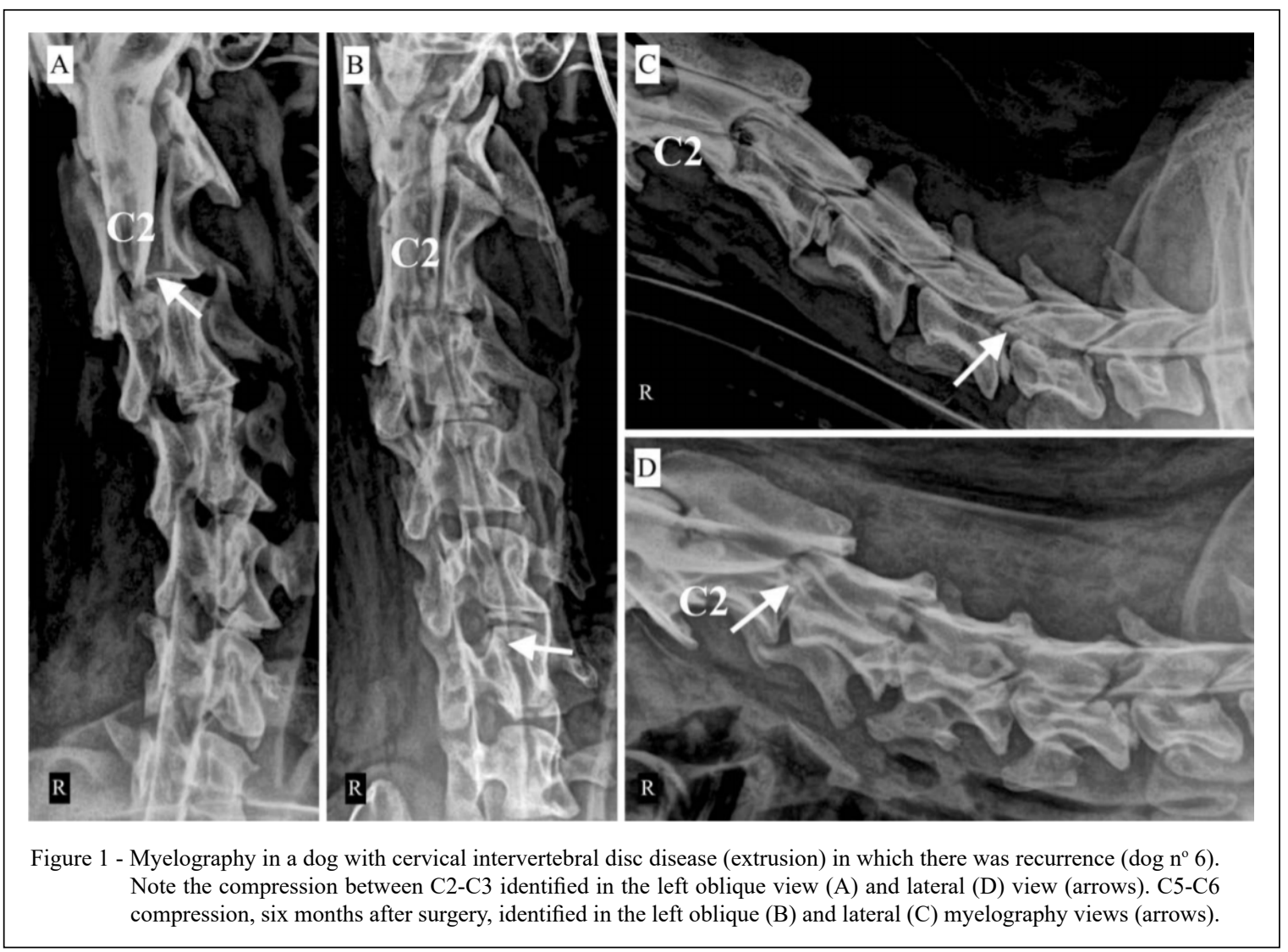

satisfactory treatment for lateralized compression. Because the hemilaminectomy is technically more difficult, more invasive and has more complications (FELTS \& PRATA 1983, TANAKA et al., 2005), the authors of this study suggested the use of the ventral slot, even for lateralized compression, as a surgical option.

One limitation of this study was the impossibility of evaluating, in the postoperative and by imaging, if the ventral slot technique promoted total decompression of the spinal cord. However, as demonstrated by the research of BÖTTCHER et al. (2013), the presence of material in the vertebral canal after ventral slot surgery in patients with complete clinical recovery is common, and this was not relevant to cause clinical signs in these patients. Even so, we suggested further studies to evaluate this variable in patients with lateralized lesions and who underwent the decompression technique through the ventral slot. Another limitation was the non-inclusion of a group of patients submitted to hemilaminectomy, with the purpose of comparing and determining superiority between this technique and the ventral slot.
The collection of data from clinical records and the execution of questionnaires to owners, characterizing this study as retrospective, means that the results reported should be interpreted with caution. Furthermore, all epidemiological studies involving questionnaires are subject to biased results (LEVINE et al., 2007).

The clinical relevance of this study was to demonstrate that the ventral slot surgical technique, even with limited access of the lateral and dorsal vertebral canal, may be a surgical alternative in the clinical recovery of dogs presenting lateralized compression by cervical IVDD, independent of the degree of neurological dysfunction. Thus, in addition to hemilaminectomy, the surgeon may opt for the ventral slot with the possibility of surgical success.

\section{CONCLUSION}

The ventral slot decompression technique promotes satisfactory clinical recovery of dogs with cervical IVDD, even in the presence of lateralized compressions of the spinal cord. 


\section{ACKNOWLEDGEMENTS}

We thank Coordenação de Aperfeiçoamento de Pessoal de Nível Superior (CAPES) for the Master and Doctorate research grants and Conselho Nacional de Desenvolvimento Científico e Tecnológico (CNPq) - process number 307120-2017-1.

\section{ETHICS COMMITTEE}

This study was approved by the Ethics Committee on Animal Use (CEUA), form the 69 Universidade Federal de Santa Maria (UFSM) by protocol number 6553011217.

\section{DECLARATION OF CONFLICT OF INTERESTS}

The authors declare no conflict of interest. The founding sponsors had no role in the design of the study; in the collection, analyses, or interpretation of data; in the writing of the manuscript, and in the decision to publish the results.

\section{AUTHORS' CONTRIBUTIONS}

MLS, GA and AM conceived and designed experiments. MLS, DAF, AR, MRW, JSR, SSM performed the experiments. LFSH and ACTC performed statistical analyses of experimental data. MLS prepared the draft of the manuscript. All authors critically revised the manuscript and approved of the final version.

\section{REFERENCE}

AIKAWA, T. et al. Recurrent thoracolumbar intervertebral disc extrusion after hemilaminectomy and concomitant prophylactic fenestration in 662 chondrodystrophic dogs. Veterinary Surgery, v.41, p.381-390, 2012. Available from: <https://www.ncbi.nlm. nih.gov/pubmed/22380868>. Accessed: Nov. 19, 2018. doi: 10.1111/j.1532-950X.2012.00970.x.

BÖTTCHER, P. et al. Effect of ventral slot procedure on spinal cord compression in dogs with single static intervertebral disc disease: preliminary findings while evaluating a semiquantitative computed tomographic myelographic score of spinal cord compression. Veterinary Surgery, v.42, p.383-391, 2013. Available from: $<$ https://www.ncbi.nlm.nih.gov/pubmed/23240963>. Accessed: Nov. 19, 2018. doi: 10.1111/j.1532-950X.2012.01067.x.

BRISSON, B.A. Intervertebral disc disease in dogs. Veterinary Clinics of North America: Small Animal Practice, v.40, p.829858, 2010. Available from: <https://www.ncbi.nlm.nih.gov/ pubmed/20732594>. Accessed: Nov. 19, 2018. doi: 10.1016/j. cvsm.2010.06.001.

BRISSON, B.A. Intervertebral disc fenestration. In: SHORES, A.; BRISSON, B.A. Current Techniques in Canine and Feline Neurosurgery. New Jersey: Wiley Blackwell, 2017. Cap.22, p.191-198.

BRISSON, B.A. et al. Recurrence of thoracolumbar intervertebral disk extrusion in chondrodystrophic dogs after surgical decompression with or without prophylactic fenestration: 265 cases (1995-1999). Journal of the American Veterinary Medical Association, v.244, p.1808-1814, 2004. Available from: <https:// avmajournals.avma.org/doi/10.2460/javma.2004.224.1808>. Accessed: Nov. 19, 2018. doi: 10.2460/javma.2004.224.1808.

CHAVES, R.O. et al. Neurological diseases in dogs examined at the Veterinary Teaching Hospital of the Federal University of Santa Maria, RS: 1.184 cases (2006-2013). Pesquisa Veterinária Brasileira, v.34, p.996-1001, 2014. Available from: <http://www. scielo.br/pdf/pvb/v34n10/12.pdf>. Accessed: Nov. 19, 2018. doi: 10.1590/S0100-736X2014001000012.

DA COSTA, R.C. Ventral cervical decompression. In: SHORES, A.; BRISSON, B.A. Current Techniques in Canine and Feline Neurosurgery. New Jersey: Wiley Blackwell, 2017. Cap.17, p.156-161.

DE RISIO, L. et al. Association of clinical and magnetic resonance imaging findings with outcome in dogs with presumptive acute noncompressive nucleous pulposus extrusion: 42 cases (2000-2007). Journal of the American Veterinary Medical Association, v.234, p.495-504, 2009. Available from: <https:// www.ncbi.nlm.nih.gov/pubmed/19222359>. Accessed: Nov. 19, 2018. doi: 10.2460/javma.234.4.495

FAUBER, A.; BERGMANN, R., 2017. Lateral cervical approach. In: SHORES, A.; BRISSON, B.A. Current Techniques in Canine and Feline Neurosurgery. New Jersey: Wiley Blackwell, 2017. Cap.18, p.163-167.

FITCH, R.B., et al. Caudal cervical intervertebral disk disease in the small dog: role of distraction and stabilization in ventral slot decompression. Journal of the American Veterinary Medical Association, v.36, p.68-74, 2000. Available from: <https://www. ncbi.nlm.nih.gov/pubmed/10667409>. Accessed: Nov. 19, 2018. doi: 10.5326/15473317-36-1-68.

FELTS, J.F.; PRATA, R.G. Cervical disk disease in the dog: intraforaminal and lateral extrusions. Journal of the American Veterinary Medical Association, v.19, p.755-760, 1983.

FINGEROTH, J.M. Dorsal cervical decompression (laminectomy/ hemilaminectomy and laminotomy). In: SHORES, A.; BRISSON, B.A. Current Techniques in Canine and Feline Neurosurgery. New Jersey: Wiley Blackwell, 2017. Cap.16, p.149-156.

GRIFFIN, J.F. Canine thoracolumbar intervertebral disk disease: pathophysiology, neurologic examination and emergency medical therapy. Compendium on Continuing Education for the Practising Veterinarian, v.31, 2009, p.1-13. Available from: $<$ https://www.ncbi.nlm.nih.gov/pubmed/19412899>. Accessed: Nov. 19, 2018.

HANSEN, H.J. A pathologic-anatomical study on disc degeneration in dog: with special reference to the so-called enchondrosis intervertebralis. Acta Orthopaedica Scandinavica, v.23, p.1-130, 1952

JENSEN, V.F. et al. Quantification of the association between intervertebral disk calcification and disk herniation in dachshunds. Journal of the American Animal Hospital Association v.233, p.1090-1095, 2008. Available from: <https:/www.ncbi.nlm.nih. gov/pubmed/18828719>. Accessed: Nov. 19, 2018. doi: doi: 10.2460/javma.233.7.1090.

KONAR, M. et al. Ventral intraspinal cysts associated with the intervertebral disc: magnetic resonance imaging observations in seven dogs. Veterinary Surgery v.37, p.94-101, 2008. Available 
from: $\quad<$ https://www.ncbi.nlm.nih.gov/pubmed/18199062>. Accessed: Nov. 19, 2018. doi: 10.1111/j.1532-950X.2007.00353.x.

LEVINE, J.M. et al. Evaluation of the success of medical management for presumptive thoracolumbar intervertebral disk herniation in dogs. Veterinary Surgery, v.36, p.482491, 2007. Available from: <https://www.ncbi.nlm.nih.gov/ pubmed/17614930>. Accessed: Nov. 19, 2018. doi: 10.1111/j.1532950X.2007.00295.x.

LIPSITZ, D.; BAILEY, C.S. Lateral approach for cervical spinal cord decompression. Progress in Veterinary Neurology, v.3, p.39-44, 1992.

LIPSITZ, D.; BAILEY, C.S. Clinical use of the lateral cervical approach for cervical spinal cord and nerve root disease: eight cases. Progress in Veterinary Neurology, v.6, p.60-65, 1995

ROSSMEISL, J.H. et al. A modified lateral approach to the canine cervical spine: procedural description and clinical application in 16 dogs with lateralized compressive myelopathy or radiculopathy. Veterinary Surgery, v.34, p.436-444, 2005. Available from: $<$ https://www.ncbi.nlm.nih.gov/pubmed/16266334>. Accessed: Nov. 19, 2018. doi: 10.1111/j.1532-950X.2005.00066.x.

ROSSMEISL, J.H. et al. Acute adverse events associated with ventral slot decompression in 546 dogs with cervical intervertebral disc disease. Veterinary Surgery, v.42, p.795-806, 2013. Available from: $\quad<$ https://www.ncbi.nlm.nih.gov/pubmed/23980621>. Accessed: Nov. 19, 2018. doi: 10.1111/j.1532-950X.2013.12039.x.

SEIM, H.B.; PRATA, R.G. Ventral decompression for the treatment of cervical disk disease in the dog: a review of 54 cases. Journal of the American Animal Hospital Association, v.18, p.233-240, 1982.

SCHMIED, O. et al. Effectiveness of cervical hemilaminectomy in canine Hansen type I and type II disc disease: a retrospective study. Journal of the American Animal Hospital Association v.47, p.342-350, 2011. Available from: <https://www.ncbi.nlm.nih. gov/pubmed/21852506>. Accessed: Nov. 19, 2018. doi: 10.5326/ JAAHA-MS-5604.

SMITH, B.A. et al. Ventral slot decompression for cervical intervertebral disc disease in 112 dogs. Australian Veterinary Practitioner, v.27, p.58-64, 1997.

TANAKA, H. etal. Usefulness of hemilaminectomy for cervical intervertebral disk disease in small dogs. Journal Veterinary Medical Science v.67, p.679-683, 2005. Available from: <https://www.ncbi.nlm.nih.gov/ pubmed/16082115>. Accessed: Nov. 19, 2018. doi: 10.1292/jvms.67.679.

TAYLOR-BROWN, F.E. et al. Risk factors for early port-operative neurological deterioration in dogs undergoing a cervical dorsal laminectomy or hemilaminectomy: 100 cases (2002-2014). The Veterinary Journal, v.206, p.327-331, 2015. Available from: $<$ https://www.ncbi.nlm.nih.gov/pubmed/26542365>. Accessed: Nov. 19, 2018. doi: 10.1016/j.tvj1.2015.10.010 